\title{
The Role of Painting Activity as an Emotional Regulation in Children with Asperger Syndrome
}

\author{
Lia Mareza, Agung Nugroho
}

\begin{abstract}
Children with Asperger syndrome still need to be adjusted, in regulating their emotion, to their enjoyment in an activity that will be their emotional allocation. Art is able to improve their self-ability, to strengthen their self-confidence, and also to re-shape lack of knowledge about their own identity. This is because activity of art becomes a collection of inspiration, the aspect of imagination that is closely related to the aesthetic experience. This was a qualitative research as a study intended to understand the phenomenon of something that is experienced by the subject of research. For example: behaviour, perception, motivation, and action in holistic way and described in form of words and language, in a specific-natural context and by utilizing various methods. The research findings show that ability of emotional regulation is the ability of the subject in receiving and understanding a command, and then in minimizing tantrum, so that the subject is able to achieve a treatment therapy; including the subject's ability to identify and draw an object or other objects around them, to recognize some painting tools and to answer questions orally or in writing through the image media. The therapy can be packaged through art education based on painting activity which is the advantage of an area itself. Schools present learning programs that also support character education and the creative potential of the children, so that they can live independently later.
\end{abstract}

Index Terms: Painting Activity, Emotional Regulation, Asperger Syndrome/Autisme.

\section{INTRODUCTION}

Many characteristics of children with special needs that require special education services due to developmental disorders and abnormalities. Asperger's Syndrome has not had many references as a foundation for the diagnosis of children, but mentioned by Klin \& Volkmar in Dinie Ratri (2016) that children with Asperger syndrome are characterized by a qualitative disadvantage in social interaction, but having normal intelligence above the average level. Other references state that tendency of mastery or passion in a particular interest or two interests that dominates the children's timing and speech direction which is still one way and excessive indulgence on one thing/object, so it makes them neglecting other activities. Children interests such as interest in art, admiration in perspective, detail or architecture is because children with Asperger syndrome have normal intelligence, even superior intelligence. They

Revised Manuscript Received on August 22, 2019.

Lia Mareza, PGSD-FKIP, Universitas Muhammadiyah Purwokerto,

Purwokerto, Indonesia

Agung Nugroho,PGSD-FKIP, Universitas Muhammadiyah Purwokerto, Purwokerto, Indonesia have high enough skills and intelligence, especially in the fields of informatics, mathematics, arts and other fields without involving a social interaction. (Dito, 2015).

Eisner (2002) in Lisa, Karen \& John (2018) explained that art has many positive influences on child development. It was known that art can improve self-ability, strengthen the confidence of a child and also able to reshape lack of knowledge about their own identity. This is because artistic activities become collection of inspiration, the aspect of imagination that is closely related to aesthetic experience of a person. The aesthetic experience associated with a visual object in a field of paper and canvas can be an expression of sense or experience as art works; one of the works is painting. The creative process in creating a work of art besides aesthetic experience is also related to emotion occurring at the timing of the art work making. Emotions in this case is soul expression to be expressed naturally, thus making the artwork as an emotional exploitation in the process of making it. (Damajanti, 2006). A person can make an emotional situation in evaluating a condition of stress and emotional experience. Conditions of evaluating can be said as an effort in suppressing emotions to be expressed. Individuals can control overflow of emotions, so that emotions can be stabilized again. This demonstrates an individual's ability to regulate emotions so as to maintain emotional stability.

Emotions in children are very dependent on the situation and condition when an event occurs. In normal children, emotions can be expressed with fun things or by playing with friends to eliminate negative emotion or stress. According to Lazarus and Folkman (in Santrock, 2003) stress conditions can occur when there is a gap or imbalance between capabilities and demands. The demands are pressures that cannot be ignored, because if they do not get them, it will cause unpleasant consequences for the children. Demands can be defined as physical and social conditions of a situation to be responded through physical or mental action by the children or individual, in an attempt to have self-adjustment. When a child has not been able to adapt or not to develop according to his age, it can be concluded that the child has a disruption in the process of development. Irvine \& Susana (2006) found that therapy using art had a huge role in providing opportunities to express and share the feelings, to escape from fatigue, and to have freedom of expression without fear. Children become confident and able to express their feelings totally to the people around, especially to adults. The need of strategy of emotional

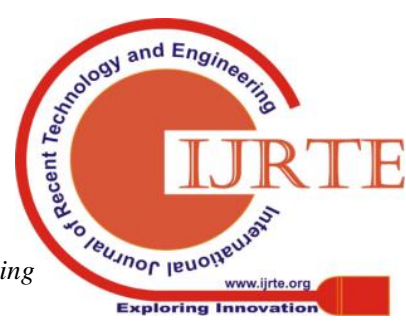


regulation in correlation between painting activities with the development of emotional regulation in children and to figure out factors affecting them to the interest for painting. This study is a form of work that manifests and relates to emotional experiences in children with Asperger Syndrome. So, the problem was formulated in questions; how the role of painting activities as emotional regulation in children/teenagers with Asperger syndrome? How if the role of painting can intervene the children, so it was able to make them "normal"?

\section{LITERATURE REVIEW}

Emotion in a person is a feeling in a biological and psychological conditions that has a tendency to act. It is a reaction as a stimulus from the outside and inside of each individual (Goleman, 2005). Emotional regulation according to Reivich and Shatté (2002) emotional regulation is the ability to remain calm under pressure. Individuals who have the ability to regulate emotions can control him/herself when he/she is upset and can overcome anxiety, sadness, or anger so it can accelerate to solve problems. Emotional expression, both negative and positive ones, is healthy and constructive as long as it is done properly. Appropriate emotional expression according to Reivich and Shatté (2002) is one of the capabilities of a resilient individual.

Painting is an activity to shape the image, using many choices of techniques and tools. Fine art activities can be used as media in the process of educating children. The meaning of education that uses art as a media as well as therapeutic strategies for children and those with special needs, so that they are able to improve their artistic ability and ablility to express emotions that exist on them (Nanang, 2017). Media (materials and tools) is everything that can be used to visualize ideas, creativity, and desire in the work of two-dimensional art. Through the preparation, selection and processing of media and equipment and materials appropriately is expected to create a creative interest which can then improve quality of the work art created. The activity of painting is able to develop right-brain ability, by finding new experiences based on direct observation which is then poured in the form of paintings. The ability to create or produce new products or combinations of results that could formerly be called a creativity in making an art work. Styles in treatment or therapy process or learning using an integrative style of teaching is a more emphasizing style of dialogue between teachers and students, therapists with clients or researchers with their research subjects, so that the creation of a good communication nuance and directed, so that goals or targets can be achieved optimally. (Ahmad Fikri, 2017).

The making of artwork is based on the idea that creative process of art-making is a healing, improving life and a form of non-verbal communication of thoughts and feelings (Malchiodi, 2003). Creating artwork can help one to express emotions that are difficult to express in words (Gatta, Gallo \& Vianello, 2014) and his/her personality (Malchiodi, 1998). Through the object images, children can tell stories and communicate with the therapist and teacher companion. The process of making artwork as a therapy can also facilitate emotions and reduce symptoms of anxiety in children. (Kim \& KI, 2014).

The purpose of this research was to help children understanding nature and appearance of a certain feeling, to provide guidance in feelings as well as social skills, to help them developing and applying concepts and forms of activities especially for children as a means of generating motivation, talent and knowledge, and implementing programs for improvement of their motor skills.

\section{RESEARCH METHOD}

This research used a qualitative method. Problem approach method used in this research was qualitative-interpretative approach. The case studies in this study would be used to examine phenomena occurring within a certain time and examine the behaviour of relevant individuals to be researched and not manipulated. Subjects involved in this study were two students. Namely students of inclusive school, who received diagnostics as autistic spectrum persons from school psychologists and interview data from the students' parents. The procedure treatment was 6 times individually and 2 times treatment conducted classically.

\section{RESULTS AND DISCUSSION}

Preference subject A for painting, when the initial observations took place, seemed enthusiastic. In a painting session (lesson) in the school, A showed great interest and interest in painting. A could run the instructions given by the teacher of fine art painting, for example, immediately took paper and open the pastel or colour pencil case. But when the painting activity lasted 5 - 10 minutes, A will tend to behave aggressively, this was caused $\mathrm{A}$ was bored and did not focus back in completing the painting. When his/her emotion began to be unstable, then the compressive strength in colouring was harder, so it made the pastel or colour pencil quickly run out. When this happened in a classical painting treatment, the teacher and researcher would prompt him to change the colour or change the object to be made or must be coloured.

For the communication skills, subject A had been able to disclose, request or select the image and colour to make, but this response did not always occur in every classical activity session, the response shown in subject A remained unpredictable and constantly changing. The following were some of the kinds of responses indicated by subject A when the researcher made a preliminary observation. Several kinds of response to the development of communication disorders, would be a consideration in determining the target behaviour in the treatment through the model of painting treatment, as an effort to regulate emotions for the subject A.

Preference of subject B for painting, when the initial observations took place, looked casual. In the treatment session of the 
process of making painting work and in integrated school (school lesson) sessions, B showed considerable interest in painting. Subject B could execute the instructions given by the teacher well, although with limited motor skills in the case of taking a pencil or holding a it. Coarse motor coordination or how to hold a pencil was still not smooth, so the intensity of the resulting image was still not well formed. In several times, the pencil or marker used while painting was repeatedly kissed. Subject B sometimes behaved impulsively or aggressively during a painting session. B is deeply affected with the people around him. In a few observations, B often suddenly sat next to a friend or teacher and then imitated the typical word or often spoken words. During the observation, subjects B often smiled and responded positively when asked or repeatedly spoken, but rarely willing to look in the eye and often avoid touch (e.g. shake hands) or step back and forth when talking at close range to the researcher/people who were not known well.

Subject B tended to be able to follow instructions given by the teacher well, although still often must be directed by the teacher companion. Response B when distracted by something that concerned him, would usually show an impulsive attitude when performing tasks given by the teacher. For example when painting, B saw his friend who also saw it, then B would focus to his/her friends who see it and tease him/her. Subject B was also very obsessed with the transportation images at the classroom (school). The teacher said that B loves the train and bus. Information from several other teachers also mentioned, subject B was very happy with train or bus. Words that were often spoken when meeting with researchers were the Efesiensi Bus or Railway.

For the communication skills, subject B had not been able to adequately disclose, request or select the image he/she wants to create. Articulation of his/her speech was still unclear and the volume of speech was also still not stable; sometimes he/she shout loudly, sometimes mutter unclearly. Thus, B still desperately needed help or direction from teachers or companion teachers. Here are some of the behaviours shown by subject B when researchers carried out preliminary observations. Several types of developmental disorders that would be the target of behaviour change in the treatment of painting process, as a form of increased emotional regulation ability.

This study shows that what is meant by the emotional regulation ability of children with Asperger syndrome/autism is a few skills in the field of communication ability of social skills. Theoretically, the basic principle of this treatment can be described as A-B-C; i.e. A (antecedent) followed by B (behaviour) and followed by $\mathrm{C}$ (consequence). (Loovas in Handoyo, 2003). Antecedent (thing that precedes occurrence of behaviour) in form of instructions given by someone to the child. Through his/her structured teaching style, the child then understands the Behaviour (behaviour) that he or she is expected to perform after the instruction is given, and the behaviour is expected to occur again when the child has a pleasant Consequence (or behavioural consequences, or sometimes a reward). Intensive behavioural treatment can improve the lives of some individuals. The purpose of this treatment is mainly to improve understanding and adherence

of children to the rules and also stimulate creativity of children in the treatment process. This treatment generally gets significant results when done intensively, regular and consistent at an early age. In the process of painting activity, the subject was able to control him/herself while being upset / not yet in the mood and could overcome anxiety because it must be close to people who had been not known, or even angry to go rampaging because not yet accustomed with instruction from other, except his/her teachers. This suggests that subjects were beginning to be able to regulate their negative emotions. (Reivich and Shatte, 2002).

Table 1. Response of Subject $A$ and $B$ before the treatment

\begin{tabular}{|c|c|c|}
\hline Emotion & Response & \\
\hline $\begin{array}{l}\text { Aspect of } \\
\text { Emotional } \\
\text { Regulation } \\
\end{array}$ & Subject A & Subject B \\
\hline a) Rampaging & $\begin{array}{l}\text { 1) Not performing the task } \\
\text { according to the initial } \\
\text { instruction (fun to play } \\
\text { alone). }\end{array}$ & $\begin{array}{l}\text { 1) Not performing } \\
\text { the task according } \\
\text { to the initial } \\
\text { instruction (fun to } \\
\text { play alone). }\end{array}$ \\
\hline $\begin{array}{l}\text { b) Repetitive/ } \\
\text { Stereotype }\end{array}$ & $\begin{array}{l}\text { 1) Repeating the words or } \\
\text { phrases mentioned by the } \\
\text { researcher repeatedly }\end{array}$ & $\begin{array}{l}\text { 1) Walk back and } \\
\text { forth around the } \\
\text { chair }\end{array}$ \\
\hline Attitude & $\begin{array}{l}\text { 1) Occasionally see but still } \\
\text { look scared / shy and } \\
\text { sometimes not indifferent. } \\
\text { 2) Eye contact is lacking } \\
( \pm 1 \text { second). }\end{array}$ & $\begin{array}{l}\text { 1) Very interested } \\
\text { in train and } \\
\text { Efisiensi bus and } \\
\text { (do not want to } \\
\text { switch / difficult to } \\
\text { divert on another } \\
\text { image and will } \\
\text { refuse anyone } \\
\text { approaching it). } \\
\text { 2) Occasionally see } \\
\text { but still look scared } \\
\text { / shy and } \\
\text { sometimes not } \\
\text { indifferent. } \\
\text { 3) Eye contact is } \\
\text { lacking } \\
\text { ( } \pm 1 \text { second). } \\
\text { 4) Cannot say hello } \\
\text { without referrals } \\
\text { from others \& do } \\
\text { not want to look at } \\
\text { face or eyes when } \\
\text { talking with } \\
\text { researchers, } \\
5 \text { ) Unable and } \\
\text { embarrassed to } \\
\text { answer greetings or } \\
\text { questions from } \\
\text { researchers without } \\
\text { the help of a } \\
\text { companion teacher. }\end{array}$ \\
\hline Facial Expression & $\begin{array}{l}\text { 1) Embarrassed (avoided) } \\
\text { when addressed and invited } \\
\text { to joke } \\
\text { 2) Ekolalia. }\end{array}$ & $\begin{array}{l}\text { 1) Fear (defensing) } \\
\text { when approached. } \\
\text { 2) Daydreaming } \\
\text { 3) Ekolalia. }\end{array}$ \\
\hline
\end{tabular}


Table. 2. Target of painting activity

\begin{tabular}{|c|c|c|c|}
\hline \multirow[b]{2}{*}{ Short Term Goals } & \multirow{2}{*}{$\begin{array}{c}\text { Long Term } \\
\text { Goals }\end{array}$} & \multicolumn{2}{|c|}{ Short Term Goals } \\
\hline & & $\begin{array}{c}\text { Outside the } \\
\text { context of } \\
\text { painting }\end{array}$ & $\begin{array}{c}\text { In the } \\
\text { Context of } \\
\text { painting }\end{array}$ \\
\hline \multirow[t]{2}{*}{$\begin{array}{l}\text { Successful } \\
\text { completion of } \\
\text { research program: } \\
\text { Enhancing } \\
\text { Capability of } \\
\text { Emotional } \\
\text { Regulation through } \\
\text { painting activity }\end{array}$} & \multirow[t]{2}{*}{$\begin{array}{l}\text { Improving } \\
\text { mastery of } \\
\text { social skills } \\
\text { programs } \\
\text { programmed } \\
\text { by schools, } \\
\text { through } \\
\text { painting } \\
\text { activities }\end{array}$} & $\begin{array}{l}\text { 1). Willing } \\
\text { to answer } \\
\text { greetings } \\
\text { from the } \\
\text { researchers } \\
\text { or say hello } \\
\text { to the } \\
\text { researchers. }\end{array}$ & $\begin{array}{l}\text { 1). Giving } \\
\text { experience in } \\
\text { painting to feel } \\
\text { the elements of } \\
\text { art such as } \\
\text { lines, shapes, } \\
\text { colours and } \\
\text { dynamics of } \\
\text { various } \\
\text { activities of } \\
\text { painting. }\end{array}$ \\
\hline & & $\begin{array}{l}\text { 2). Making } \\
\text { eye contact } \\
\text { for more } \\
\text { than } 3 \\
\text { seconds } \\
\text { with the } \\
\text { researcher. } \\
\text { 3). } \\
\text { Identifying } \\
\text { name of } \\
\text { object } \\
\text { visually and } \\
\text { audio } \\
\text { visually. } \\
\text { 4). Can } \\
\text { carry out } \\
\text { task or } \\
\text { instruction } \\
\text { given by the } \\
\text { researcher. }\end{array}$ & $\begin{array}{l}\text { 2). Can draw } \\
\text { objects that are } \\
\text { viewed or } \\
\text { instructed } \\
\text { 3). Identifying } \\
\text { and labelling } \\
\text { name of } \\
\text { painting and } \\
\text { be able to } \\
\text { mention name } \\
\text { orally. } \\
\text { 4). Can } \\
\text { recognize } \\
\text { colour } \\
\text { according to } \\
\text { colour of } \\
\text { object and } \\
\text { improve } \\
\text { aesthetically. } \\
\text { 5). Can } \\
\text { express freely } \\
\text { in painting. }\end{array}$ \\
\hline
\end{tabular}

Creativity is often associated with something artistic, intelligent, out of the box, different, and elusive (difficult to understand). The values of novelty and authenticity are always correlated with creativity. The essence of creativity is an expression that is usually free of skill and fluency, this type of creativity is less important, it appears that talented individuals at this level of creativity are two traits: spontaneity and freedom. So, researchers deliberately choose a comfortable situation for subject such as waiting or obey the wishes of the subject until in the end willing to be invited to paint with researchers. In accordance with the stated by Gross and Thompson (2007) that selection of conditions and situations is functioned to work, so that the subject is able to express his feelings comfortably. Many kinds of media that can be used by researchers in applying art, because the art can be suitable in all age levels. It can also be held out anywhere, on the home yard, even at school.

Art is useful for the subject to express his/her feelings. Feelings of relaxation will be obtained when its flows can be felt. In that condition, the researcher should be able to keep focus and attention of the subject, so his/her painting activity keeps on, and the subject can express his/her feelings into artwork. (Gross and Thompson, 2007). In children with Asperger syndrome who are talented in field of fine arts, they usually have a very sensitive aesthetic as an advantage. The desire to taste perceived can be channelled through the artwork. Scratches that form an object with a unique perspective, making the children with Asperger syndrome with the artistic talent feel comfortable to release all that he felt. A relaxed nerves state, reducing the pressure in their brain, so their mind is not rigid and the treatment can be done when they are relaxed (relaxed).

This is where the important role of art; because when the feeling of relaxation comes, it is able to make the brain's nerve thinking in relax (positive psychology), so that when the bloodstream run smoothly, it can also trigger a calm soul. (Damajanti, 2006). In children with Asperger syndrome having special talents (autodidact painting skill), with art activities they do, they can be directed to produce/create artworks. Providing a positive reinforcement can control how they act following their favour. All the hidden flavours of the heart can appear slowly, and that is time of treatment role, the feeling of relaxation that enables art message to send properly.

Table. 3. The desired response during treatment

\begin{tabular}{|c|c|c|}
\hline Subject A & \multicolumn{2}{|c|}{ Response of ability } \\
\hline $\begin{array}{l}\text { Aspects of } \\
\text { Emotional } \\
\text { Regulation }\end{array}$ & Communication & $\begin{array}{l}\text { Painting } \\
\text { Activity }\end{array}$ \\
\hline $\begin{array}{c}\text { Emotion without } \\
\text { fear }\end{array}$ & $\begin{array}{l}\text { 1) Answering questions } \\
\text { verbally and in writing } \\
\text { (what, where, when, and } \\
\text { why). } \\
\text { 2) Answering "yes" or "no" } \\
\text { in response to the question of } \\
\text { things and deeds }\end{array}$ & $\begin{array}{l}\text { 1. Using simple } \\
\text { sentences with } \\
\text { the assistance } \\
\text { of images. } \\
\text { 2. Mentioning } \\
\text { the colour and } \\
\text { shape of the } \\
\text { image. }\end{array}$ \\
\hline Subject B & \multicolumn{2}{|c|}{ Response of ability } \\
\hline $\begin{array}{l}\text { Aspects of } \\
\text { Emotional } \\
\text { Regulation }\end{array}$ & Communication & $\begin{array}{l}\text { Painting } \\
\text { Activity }\end{array}$ \\
\hline $\begin{array}{c}\text { Emotions without } \\
\text { rampage }\end{array}$ & $\begin{array}{l}\text { 1. Identifying objects or } \\
\text { objects around. } \\
\text { 2. Answering questions } \\
\text { verbally and in writing } \\
\text { (what, where, when, and } \\
\text { why). } \\
\text { 3. Answering "yes" or "no" } \\
\text { in response to the } \\
\text { question of things and } \\
\text { deeds. }\end{array}$ & $\begin{array}{l}\text { 1. Using simple } \\
\text { sentences with } \\
\text { the assistantce of } \\
\text { images. } \\
2 . \\
\text { Mentioni } \\
\text { ng the colour and } \\
\text { shape of the } \\
\text { image. } \\
\text { 3. Hold the } \\
\text { pencils, crayons, } \\
\text { markers and } \\
\text { brushes } \\
\text { correctly. }\end{array}$ \\
\hline
\end{tabular}

Improvisation in painting

Published By:

Blue Eyes Intelligence Engineering

\& Sciences Publication 
activity is also applied in various activities. This improvement is done with the aim of providing experience in training motor sensitivity as an effort to help improving the subject emotional regulation ability. One of them is, in addition to seeing the object directly, the subject at once taught the material about the object being viewed or drawn. Another thing that is also taught besides the identification of object names, colours are also imitation deeds or actions. The process and dynamics of painting activities are carried out in various improvisations. One of them is the activity of telling stories with the researcher. In this treatment session, researchers used the image that is displayed on a laptop as a stimulus for the subject to interact and make eye contact with the researcher. So, the subject would pay attention to the instructions and able to run the task given the researchers in more maximally.

One of result achievements that was very influential on the achievement of the main target of this treatment was willingness of the subject to interact more closely with researchers and did not avoid the researchers when approached. This was shown in results of the subject's response to almost all treatments. The painting activity which for the subjects was as fun as doodling and then mixing the colour shown by the researcher, Suyanto (2005) explained that colouring and painting activity was a freedom in choosing form and combining colour element; it can be mentioned that painting was a creativity, this was proven when the subject was able to draw attention away from his work and encourage the subject to speak to the researcher. With the impression of fun in a painting activity, the subject would be easier to invite to communicate or cooperate. The results obtained during the painting activity was creation of a form of cooperation or a good relationship in a painting activity such as drawing together in order to foster self-confidence and confidence of the subject to researchers. The subject began to express emotions that are difficult to express in words (Gatta, Gallo \& Vianello, 2014). When the subject had confidence to the researcher, delivery of material would be easier to do, the child began to tell the story and communicated with the researcher through images (Kim \& $\mathrm{Ki}, 2014)$. The results of treatment showed that when the subject has been able to make eye contact on the researcher, do not avoid him/her when he/she invited to communicate and want to pay attention as a remark to the researcher, the subject would tend to be easier to accept instructions given by the researcher and the learning process can run well. This assumption was supported by Djohan (2003), who stated that art tools assistance would make the subject willing to be encouraged to interact, improvise, listen or play actively, without having to say words.
Table. 4. Response on Emotional Regulation Ability

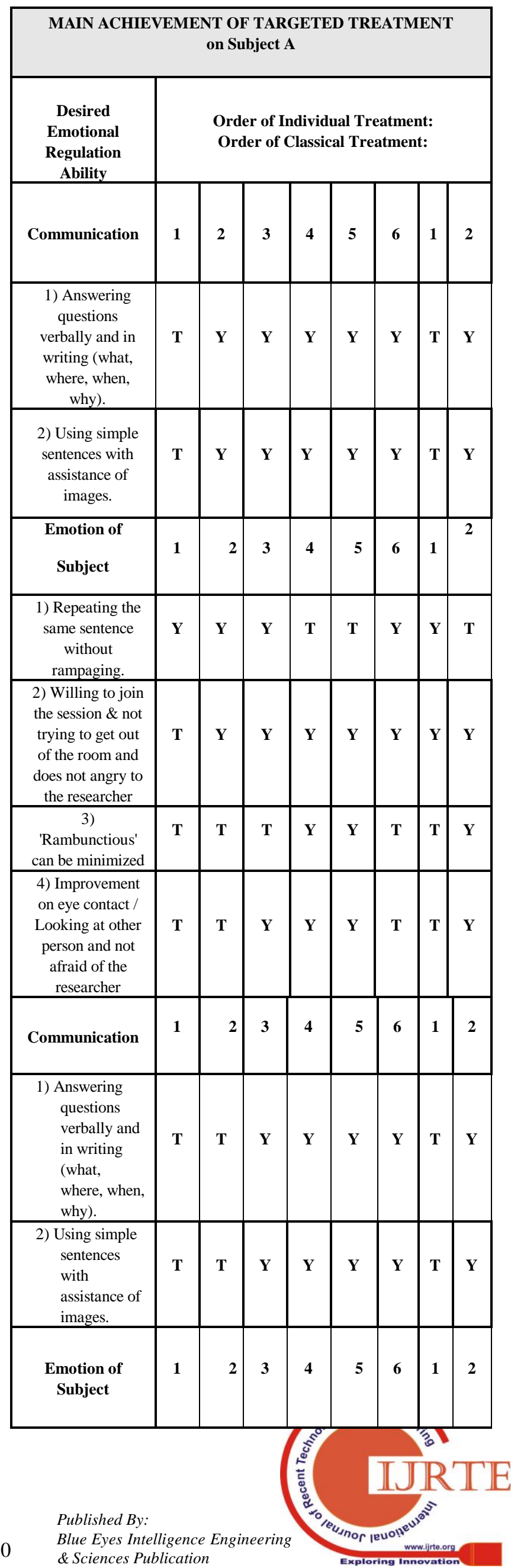




\begin{tabular}{|l|c|c|c|c|c|c|c|c|}
\hline $\begin{array}{l}\text { 1) Repeating the } \\
\text { same sentence } \\
\text { without } \\
\text { rampaging. }\end{array}$ & $\mathbf{Y}$ & $\mathbf{Y}$ & $\mathbf{Y}$ & $\mathbf{Y}$ & $\mathbf{Y}$ & $\mathbf{T}$ & $\mathbf{Y}$ & $\mathbf{Y}$ \\
\hline $\begin{array}{l}\text { 2) Willing to join } \\
\text { the session \& not } \\
\text { trying to get out } \\
\text { of the room and } \\
\text { does not angry to } \\
\text { the researcher }\end{array}$ & $\mathbf{T}$ & $\mathbf{T}$ & $\mathbf{Y}$ & $\mathbf{Y}$ & $\mathbf{Y}$ & $\mathbf{Y}$ & $\mathbf{Y}$ & $\mathbf{Y}$ \\
\hline $\begin{array}{l}\text { 3) 'Rambunctious' } \\
\text { can be minimized }\end{array}$ & $\mathbf{T}$ & $\mathbf{T}$ & $\mathrm{T}$ & $\mathrm{Y}$ & $\mathrm{Y}$ & $\mathbf{Y}$ & $\mathbf{T}$ & $\mathbf{Y}$ \\
\hline $\begin{array}{l}\text { 4) Improvement on } \\
\text { eye contact / } \\
\text { Looking at other } \\
\text { person and not } \\
\text { afraid of the } \\
\text { researcher }\end{array}$ & $\mathbf{T}$ & $\mathbf{T}$ & $\mathbf{Y}$ & $\mathbf{Y}$ & $\mathbf{Y}$ & $\mathbf{Y}$ & $\mathbf{T}$ & $\mathbf{Y}$ \\
\hline
\end{tabular}

Notes :

$$
\mathbf{Y}=\mathbf{Y a}(\mathbf{Y e s})
$$

\section{T = Tidak Tercapai $($ Not Achieved)} to make eye contact, paid attention to and was able to grasp the intent of the instruction or instruction of the researcher, the achievement of treatment targeted, showed better results. Painting activities such as playing painting tools in a certain room, could be used as a medium for delivering materials to improve ability to paint. For example, the results shown in achievement of ability to paint on imitation (model) of images in accordance with the material delivered by providing some simple lines which then responded into a particular field or object. The images provide valuable information about the development of perceptions of self and its environment (Farokhi \& Hashemi, 2011). The subject of research, when having favour on one of the objects, would describe it in all points of view, and a very logical thing to describe, because the subject was rarely, even never draw an illogical example, a bus that was running at night, so that the subject would also describe the bus reflecting light to the road. Not only painting, if subject were tired; he/she would have an interest for fiddling with objects that can be dismantled and then assembled the object properly.

During the process of painting activity, researchers asked some questions. Types of questions were varied, by linking them to the painting activity together with the researcher. Variations of painting activities favoured by the subject could be used as a "gift" when the subject was able to improvise freely in expressing him/herself or being able to communicate in two ways. The result of this treatment showed that painting activity was able to give space to the subject to be free of expression, so that he/she looked more passionate in the activity of painting and was encouraged to communicate with the researcher (Malchiodi, 2003).

\section{CONCLUSION}

The conclusion as the result of the target achievement of painting activity as the treatment model in the series of
Some treatments are found that when subjects were willing

treatment by the subject in this study shows that painting activity has an effect on the improvement of emotional regulation ability of children with Asperger syndrome or mild (minor) autism. This is regardless of the achieved or not achieved treatment target according to the definition of response. The treatment of painting activities in children with disorders or obstacles, does not provide specific targets that require the subject to reach a certain level of ability, but the children can open and express their thoughts and emotions in a supportive atmosphere, externalize difficult emotions, express positive emotions such as hope, organize and re-frame mind and make them able to plan their future. This is implemented because old-style education considers students as objects that must accept everything given by the teacher. Whereas for children with special needs, the teacher explores children's potentials and adapts to their abilities ideally, besides being able to regulate the emotions of children with special needs, the children can also be creative in the process of creating art. Secondly, it is done in educational orientation. The orientation of education now places too much emphasis on cognitive aspects, while other aspects of personality which are more important, such as affective and psychomotor aspects are neglected.

\section{REFERENCES}

1. Ahmad Fikri. (2017). Paradigma Pendidikan Seni. Editor: Deddy Irawan Yogyakarta: Thafamedia

2. Damajanti, I. (2006). Psikologi Seni. Bandung: PT. Kiblat Buku Utama

3. Dinie Ratri, D.(2016). Psikologi Anak Berkebutuhan Khusus Yogyakarta: Psikosain

4. Dito, Anugoro. (2015). Sindrom Asperger. Jurnal Cermin Dunia Kedokteran. vol. 42 no. 2, hal. 225

5. Djohan. 2003. Psikologi Musik. Yogyakarta: Buku Baik.

6. Farokhi, M \& Hashemi, M. (2011). The Analysis of Childrens Drawings Social, emotional, physical, and Psychological Aspect. Procedia - Social and Behavioral Sciences, 30. 2219-2224.

7. Gatta, M., Gallo, C \& Vianello, M. (2014). Art Therapy Groups for Adolescents with Personality Disorders. The Artsin Psychotherapy 41, $1-6$

8. Goleman, Daniel. 2005. Kecerdasan Emosi: Untuk Mencapai Puncak Prestasi. Terjemahan oleh

9. Alex Tri Kantjoro. PT. Gramedia Pustaka Utama: Jakarta.

10. Gross, J.J \& Thompson, R.A. (2007). Emotion Regulation Conceptual Handbook of Emotion Regulation, Edited By James J. Gross. New York: Guilfors Publication.

11. Handoyo, Y, 2003. Autisma: Petunjuk Praktis dan Pedoman Materi Untuk Mengajar Anak Normal, Antis dan Perilaku Lain, PT. Bhuana Ilmu Populer, Jakarta.

12. Irvine Gerch \& Susana, SGJ. (2006). Creative Arts Therapies and Educational Psychology: Let's Get Together. International Journal of Art Therapy, 11(1): 22-32

13. Kim, S. \& Ki, J. (2014). A Case Study on The Effects of The Creative Art Therapy with Stretching and Walking Meditation-Focusing On The Improvement of Emotional Expression and Alleviation of Somatisation Symptoms in A Neurasthenic Adolescent. The Art in Psychotherapy, 41 , $71-78$.

14. Lisa,F.P, Karen, P.N, John, B. (2018). Pre-service Arts Teachers' Perceptions of Inclusive Education Practice in Western Australia International Journal of Special education. Vol. 33, No. 1

15. Malchiodi, C.A. (1998). Understanding Children's Drawings. New York The Guilford Press

16. Malchiodi, C. A (2003). Handbook of Art Therapy. New York: The Guilford Press.

17. Nanang Ganda, P. (2017). Seni Rupa dan Kriya: Buku Ajar bagi Mahasiswa PGTK,PGSD, Guru PAUD dan SD. (Disesuaikan dengan Kurikulum 2013). Bandung: satu Nusa 
18. Reivich, K. dan Shatte, A. 2002. The Resilience Factor: 7 Essential skills For Overcoming Lifes

19. Inevitable Obstacles. New York: Broadway Books.

20. Santrock, J.W. 2003. Psychology. Edisi ke-7. USA: McGraw Hill

21. Suyanto, S. 2005. Dasar -Dasar pendidikan Anak Usia Dini. Yogyakarta: Hikayat

\section{AUTHORS PROFILE}

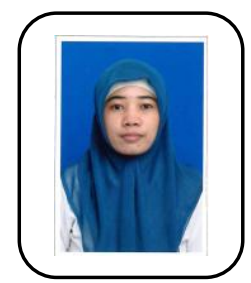

Lia Mareza The author is a lecturer in the education program of elementary school teachers with a background in fine arts education at the undergraduate level and psychology at the master's. The author also actively conducts research related to fine arts and psychology as emotional regulation and therapy for children with special needs. This research was funded by a government grant and the writer is still active in conducting research related to the science. For academic purposes, the author can be contacted via e-mail at: liamareza@yahoo.com

Agung Nugroho The author is a lecturer in the education program of elementary school teachers with a background educational in geography who also teaches and manages subjects related to the development of students and is still actively conducting research related to basic education. The writer is still active in conducting research related to the science. For academic purposes, the author can be contacted via e-mail at: agungnugroho_ump@yahoo.co.id 